\title{
Prevalence and spatial distribution of Mycobacterium leprae infection in a medium endemicity municipality
}

\author{
Prevalência e distribuição espacial da infecção pelo Mycobacterium leprae em município de \\ média endemicidade
}

Gabriela de Cássia Ribeiroํㅜㄹ Josafá Gonçalves Barreto², Isabela de Caux Bueno ${ }^{3}$, Bruna Fonseca Vasconcelos ${ }^{1}$, Francisco Carlos Félix Lana ${ }^{3}$

\begin{abstract}
Objective: analyze serological profile and spatial distribution of Mycobacterium leprae infection and disease. Methods: cross-sectional study with cases of leprosy $(n=42)$, household contacts $(n=81)$ and school contacts $(n=358)$. Interviews, dermato-neurological examination, serological and georeferencing made. Results: all seropositive cases lived in rural areas, more than two people per household, 50.0\% had alteration of foot strength. $75.0 \%$ were elderly and married participants. Among seropositive schoolchildren, $75.0 \%$ female, $69.4 \%$ lived with more than four people $80.6 \%$ slept in the bedroom with someone. It was possible to observe hyper endemic areas of cases in the studied municipality and spatial-temporal relation among them $(\mathrm{p}=0.010)$. In addition, concentration of cases and schoolchildren in sectors of lower family income per capita was found. Conclusion: the serological analysis revealed that the cohabitation condition was related to the Mycobacterium leprae infection, and the spatial analysis showed a hidden endemic scenario.
\end{abstract}

Descriptors: Leprosy; Spatial Analysis; Serology; Epidemiological Monitoring.

Objetivo: analisar o perfil sorológico e a distribuição espacial da infecção e do adoecimento pelo Mycobacterium leprae. Métodos: estudo transversal, conduzido com casos de hanseníase $(\mathrm{n}=42)$, contatos intradomiciliares $(\mathrm{n}=81)$ e escolares $(\mathrm{n}=358)$. Realizados entrevista, exame dermatoneurológico, sorológico e georreferenciamento dos endereços. Resultados: dos casos soropositivos, todos residiam em zona rural, com mais de duas pessoas no domicílio, 50,0\% apresentavam alguma alteração de força nos pés. Dos contatos soropositivos, 75,0\% eram idosos e casados. Dentre os escolares, $75,0 \%$ eram do sexo feminino, $69,4 \%$ residiam com mais de quatro pessoas e $80,6 \%$ dormiam no quarto com alguém. Foi possível observar áreas hiperendêmicas de casos no munícipio estudado e relação espaço-temporal entre eles $(\mathrm{p}=0,010)$. Além disso, concentração de casos e escolares em setores de menor renda familiar per capita. Conclusão: a análise sorológica revelou que a condição de convivência se relacionou com a infecção pelo Mycobacterium leprae, e a espacial demonstrou cenário de endemia oculta.

Descritores: Hanseníase; Análise Espacial; Sorologia; Monitoramento Epidemiológico.

\footnotetext{
${ }^{1}$ Universidade Federal dos Vales do Jequitinhonha e Mucuri. Diamantina, MG, Brazil.

${ }^{2}$ Universidade Federal do Pará. Castanhal, PA, Brazil.

${ }^{3}$ Universidade Federal de Minas Gerais. Belo Horizonte, MG, Brazil.
} 


\section{Introduction}

Leprosy is a disease that persists as a public health problem in Brazil, it has a heterogeneous distribution in the national territory and affects the economically most vulnerable population ${ }^{(1-2)}$. Most Brazilian municipalities face challenges in complying with the principles of epidemiological surveillance of leprosy, such as early detection and treatment of new cases, decentralization of prevention and control actions, in order to integrate them into Primary Health Care and surveillance of household and social contacts ${ }^{(1)}$.

This reality is experienced by the municipality of Diamantina, located in the Jequitinhonha Valley, Brazil. Between 2001 and 2016, there was a variation of the rate of endemic between medium and very high, with periods of absence of diagnosis, in addition to the coefficient of degree of disability higher than the national average ${ }^{(3)}$.

Since 1998, the World Health Organization has pointed out the importance of developing technologies capable of detecting infection with Mycobacterium leprae ${ }^{(4)}$, anticipating the appearance of the first signs and symptoms of leprosy. As a strategy are the serological tests that may be of great importance in detecting the presence of immunoglobulin M (IgM) or immunoglobulin G (IgG) antibodies against Mycobacterium leprae specific proteins. The most commonly used is IgM anti-phenol glycolipid antibody detection (PGL-1) and can be performed by Enzyme-Linked Immunosorbent Assay (ELISA) or rapid lateral flow test (ML FLOW) ${ }^{(5-6)}$.

Studies have shown that these tests are able to help in the identification of exposed individuals with subclinical infection or early stage disease and are important indicators of the magnitude of leprosy burden in a given $\operatorname{area}^{(7-8)}$.

Spatial analysis is also a tool that has been widely used since the physical distance between patients and their cohabitants can determine groups at risk of becoming ill, which reinforces the importance of including social contacts in research, especially in hyper endemic and high concentration areas population ${ }^{(8-9)}$. Therefore, the recognition of the serological characteristics and the spatial distribution pattern of Mycobacterium leprae disease and infection becomes essential for leprosy surveillance, since they contribute to the establishment of the epidemiological profile of the disease and allow the planning of control actions in the different areas regardless of the level of endemism.

Therefore, the objective was to analyze the serological profile and spatial distribution of infection and Mycobacterium leprae disease.

\section{Methods}

This is a cross-sectional and retrospective study, carried out in the municipality of Diamantina (Vale do Jequitinhonha, Minas Gerais, Brazil), whose population is approximately 47,800 people.

The research involved two population groups. The first consisted of leprosy cases reported between 2001 and 2014 and their household contacts. A total of 91 cases were diagnosed. The cases and contacts approach was carried out between August and December 2016. The database of the National Disease Notification System was used to identify cases and clinical-epidemiological information. Subsequently, an interview was conducted through a semi-structured instrument, containing socioeconomic, demographic, housing and living conditions, clinical history of the case or contact with leprosy. A simplified dermato-neurological examination was also performed. Finally, participants were submitted to peripheral blood collection for serological examination.

The second population group consisted of students aged seven to 14 years, enrolled in the state schools of Diamantina, Brazil. By 2015, there were approximately 4,000 people with this same profile. For the sample calculation, we considered the prevalence of anti-PGL- 1 positivity of $30.0 \%$ and the confidence interval of $95.0 \%$, obtaining a value of 300 children. This value was increased by $20.0 \%$ to cover possible 
losses and stratified by the proportion of students enrolled in participating state schools, reaching the final number of 363 individuals.

The students were approached in the classroom between April and May 2017. The individual interview was conducted, with an average time of 15 minutes, in a place given by the school. The semi-structured questionnaire contained socioeconomic, demographic, household coexistence and presence of skin blemishes. At the end, they were also submitted to peripheral blood collection for serological testing.

The blood collected in VACUTAINER $®$ BD tube with separator gel and vacuum adaptation was fractionated in aliquots of $500 \mu \mathrm{l}$ of serum, stored in a freezer, duly identified. The ELISA test to analyze the presence of anti-PGL-1 IgM antibodies was performed according to standard protocol ${ }^{(6)}$. For the examination, the natural-octyl-HSA disaccharide (ND-O-HSA) was used. Samples and controls were tested in duplicate and the antibody titre was expressed in sample optical density/cut-off optical density. ELISA Index values greater than 1.10 were considered positive. The reading was in a spectrophotometer at $492 \mathrm{~nm}$ of absorbance ${ }^{(6)}$. The ELISA was repeated for samples displaying ELISA index values, classified as positive in a single well of the duplicate, and samples whose values exhibited $25.0 \%$ or more of variation between the duplicate ${ }^{(10)}$.

The database was written in Epi Info software version 3.5.1. After double typing and correction of inconsistencies, the data were compiled and analyzed by Statistical Package for Social Sciences, IBM, New York, USA, version 25.

The dependent variable was anti-PGL-1 serum positivity. The independent variables correspond to the socioeconomic and demographic factors: sex, schooling, family income, residence time in the address, number of rooms and rooms in the house, number of residents in the same house and in the same room; clinical history and presence of blemishes on the body.

Descriptive statistical analyzes were performed to obtain average, standard deviation and relative and absolute frequencies. The association between categorical variables was assessed by Chi-Square $\left(\mathrm{x}^{2}\right)$ or Fisher's exact test. The normality of the data was assessed by the Kolmogorov-Smirnov test. The data were submitted to the Mann-Whitney test to verify the association of quantitative variables between positive and negative serology. The level of significance was set at $\mathrm{p}<0.05$.

All addresses that could be georeferenced were processed by the free software Geographic Information System (QGIS), version 2.18.0, and georeferenced satellite image showing the urban spot of the city of Diamantina. The urban census tracts of the municipality were used as a unit of aggregation.

The cases of leprosy were distributed by census tracts to identify the detection rate and, through the Moran Global correlation I, a statistical relationship between the observed values was verified. The Local Spatial Association I (or local Moran) test was performed in the GeoDA software to identify the range within which the correlation was positive. A Kulldorff spatial scan statistic was used to identify leprosy risk cluster and Knox's local test to detect the spatial-temporal interaction of individual cases over a period of three years and a space of 100 meters, both in the ClusterSeer2 software.

The research followed the recommendations of the Helsinki Protocol and Resolution 466/12 of the National Council of Ethics in Research involving human beings, and was approved by the Ethics Committee of the Federal University of Minas Gerais, according to opinion no $\mathbf{1}, 484,201$.

\section{Results}

Of the 91 reported cases, $42(46.1 \%)$ were interviewed. Twenty were not found, 18 died, five moved, five refused, and one was excluded for misdiagnosis. 81 contacts were found. The average age was 56.4 years and standard deviation ( $\mathrm{sd} \pm 15.6$ ) for the cases and 42.4 years ( $s d \pm 20.3$ ) for the contacts. Fe- 
males prevailed in the two population groups, 68.3 and $58.0 \%$, respectively. The anti-PGL-1 positivity was low among cases and contacts, corresponding to 9.5 and 5\%, respectively.

Table 1 shows that the presence of anti-PGL-1 IgM antibodies was associated with the fact that $100.0 \%$ of the positive cases live in the rural area $(\mathrm{p}=0.016)$, living with more than two people at home $(p=0.035)$ and to the fact that $50.0 \%$ of the cases presented a change in the strength of the feet $(p=0.005)$.

In relation to contacts of seropositive leprosy (Table 1), there was a statistical significance of $75.0 \%$ in the age group corresponding to the elderly $(p=0.038)$ and the spouses of the cases $(p=0.035)$.

Of the 358 schoolchildren in the study, 36 (10.1\%) had anti-PGL-1 positivity. Their average age was 11 years ( $\operatorname{sd} \pm 1.96$ ).

Table 2 shows that serum positive participants were constituted $75.0 \%$ of the female sex $(\mathrm{p}=0.032)$, $69.4 \%$ lived with more than four people at home $(p=0.027)$ and $80.6 \%$ shared the room with another person $(\mathrm{p}=0.043)$.
Table 2 - Association of socioeconomic, demographic, cohabitation, knowledge about leprosy, BCG scar and presence of spots in students and anti-PGL-1 serology

\begin{tabular}{|c|c|c|}
\hline \multirow[b]{2}{*}{ Variables } & \multicolumn{2}{|c|}{ Serology } \\
\hline & $\begin{array}{c}\text { Negative } \\
\text { n (\%) }\end{array}$ & $\begin{array}{c}\text { Positive } \\
\text { n (\%) }\end{array}$ \\
\hline
\end{tabular}

\section{Gender}

Female

180 (55.9) $27(75.0) \quad 0.032$

Male

$142(44.1) \quad 9(25.0)$

Zone

Urban

300 (93.2) 33 (91.7) 0.471

Rural

22 (6.8) 3 (8.3)

Number of people in the household

$$
\begin{aligned}
& \leq 4 \\
& 161 \text { (50.0) } 11 \text { (30.6) } 0.027 \\
& >4 \\
& 161(50.0) 24(69.4)
\end{aligned}
$$

He sleeps in the bedroom with someone

\begin{tabular}{|c|c|c|c|c|c|c|}
\hline \multirow[b]{2}{*}{ Variables } & \multicolumn{3}{|c|}{ Cases } & \multicolumn{3}{|c|}{ Contacts } \\
\hline & $\begin{array}{c}\text { Negative } \\
\text { n (\%) }\end{array}$ & $\begin{array}{c}\text { Positive } \\
\text { n (\%) }\end{array}$ & $\mathbf{p}$ & $\begin{array}{c}\text { Negative } \\
\text { n (\%) }\end{array}$ & $\begin{array}{c}\text { Positive } \\
\text { n (\%) }\end{array}$ & $\mathbf{p}$ \\
\hline \multicolumn{7}{|l|}{ Zone } \\
\hline Urban & $26(68.4)$ & - & \multirow{2}{*}{0.016} & $55(71.4)$ & $2(50.0)$ & \multirow[t]{2}{*}{0.340} \\
\hline Rural & $12(31.6)$ & $4(100.0)$ & & $22(28.6)$ & $2(50.0)$ & \\
\hline \multicolumn{7}{|l|}{ Age group } \\
\hline Child / adolescent & - & - & \multirow[b]{2}{*}{0.313} & $10(13.0)$ & - & \multirow[b]{2}{*}{0.038} \\
\hline Adult & $16(42.1)$ & $3(75.0)$ & & $49(63.6)$ & $1(25.0)$ & \\
\hline \multicolumn{7}{|l|}{ Years of study } \\
\hline$<1$ & $10(26.3)$ & $2(50.0)$ & \multirow{3}{*}{0.638} & $9(11.7)$ & $2(50.0)$ & \multirow{3}{*}{0.121} \\
\hline $1-8$ & $21(55.3)$ & $1(25.0)$ & & $36(46.8)$ & $1(25.0)$ & \\
\hline$\geq 9$ & $7(18.4)$ & $1(25.0)$ & & $32(41.6)$ & $1(25.0)$ & \\
\hline \multicolumn{7}{|l|}{ Kinship grade (case) } \\
\hline Spouse & - & - & & $18(23.4)$ & $3(75.0)$ & \multirow{3}{*}{0.035} \\
\hline Blood related & - & - & & 40 (51.9) & $1(25.0)$ & \\
\hline Non-consanguineous & - & - & & 19 (24.7) & - & \\
\hline \multicolumn{7}{|l|}{ Family income (salary) } \\
\hline$>2$ & $10(26.3)$ & $2(50.0)$ & 0.320 & $24(31.2)$ & $1(25.0)$ & 0.637 \\
\hline \multicolumn{7}{|c|}{ Number of people (household) } \\
\hline$\leq 2$ & $23(60.5)$ & - & \multirow[t]{2}{*}{0.035} & $19(24.7)$ & $3(75.0)$ & \multirow[t]{2}{*}{0.059} \\
\hline$>2$ & $15(39.5)$ & $4(100.0)$ & & $58(75.3)$ & $1(25.0)$ & \\
\hline \multicolumn{7}{|l|}{ Change hands strength } \\
\hline Strong & $17(44.7)$ & $3(75.0)$ & \multirow{3}{*}{0.267} & $70(90.9)$ & $4(100.0)$ & \multirow{3}{*}{0.692} \\
\hline Decreased & $21(55.3)$ & $1(25.0)$ & & $7(9.1)$ & - & \\
\hline Paralyzed & - & - & & - & - & \\
\hline \multicolumn{7}{|l|}{ Change foot strength } \\
\hline Strong & $34(89.5)$ & $2(50.0)$ & \multirow{3}{*}{0.005} & $76(98.7)$ & $04(100.0)$ & \multirow{3}{*}{0.951} \\
\hline Decreased & $4(10.5)$ & $1(25.0)$ & & $1(1.3)$ & - & \\
\hline Paralyzed & - & $1(25.0)$ & & - & - & \\
\hline
\end{tabular}

\begin{tabular}{llll} 
No & $118(36.6)$ & $7(19.4)$ & 0.043 \\
Yes & $204(63.4)$ & $29(80.6)$ & \\
Presence of skin blemishes & & & \\
No & $128(39.8)$ & $9(52.8)$ & 0.132 \\
Yes & $194(60.2)$ & $17(47.2)$ & \\
\hline
\end{tabular}

Table 1 - Association between socioeconomic, demographic, case clinical characteristics and contacts of leprosy and anti-PGL-1 serology 
Figure 1A shows the rate of detection of leprosy by census tracts and areas classified as hyper-endemic and other silent. Figure 1B shows that the concentration of cases and schoolchildren are in sectors of lower family income per capita and that the areas of

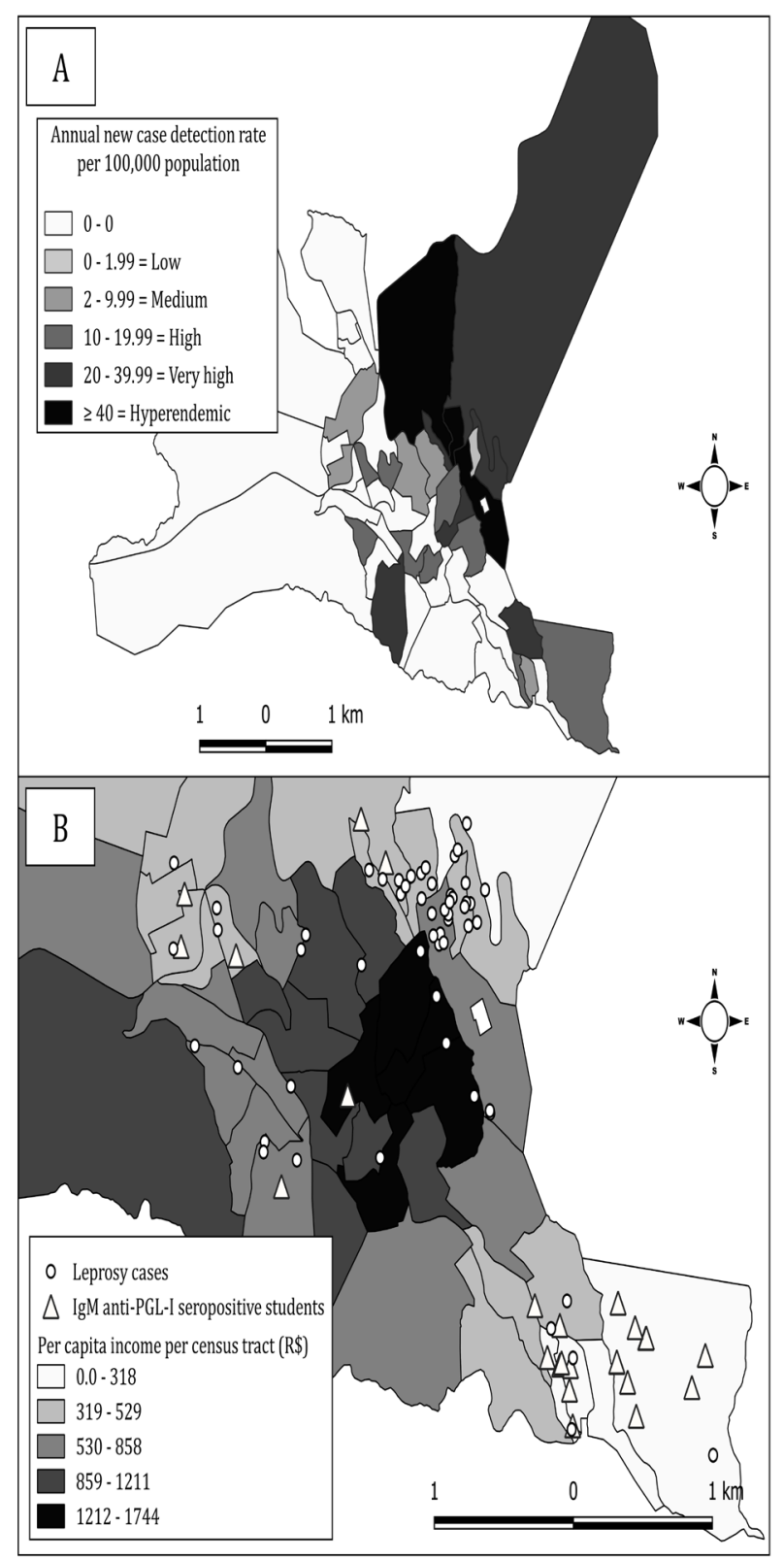

Figure 1 - A) Rate of detection of new cases of leprosy among the urban census tracts. B) Spatial-temporal relationship between cases and cluster of schoolchildren illness and anti-PGL-1 seropositive differ spatially. There was also a spatial-temporal relationship between the cases diagnosed with three years of difference and residents within the 100 -meter radius $(\mathrm{p}=0.010)$.

\section{Discussion}

The time between the diagnosis of the cases and the carrying out of this investigation was considered a limitation of this study, which may have generated memory bias and reduced the serological level between the groups, especially among the home contacts. However, there are explanations in the literature for these findings, since there is a possibility of reduction in the titre of anti-PGL-1 IgM antibodies, due to the decrease in the bacillary load after the end of the poly chemotherapy ${ }^{(10-12)}$ of the interviewed cases.

Studies in different regions of Brazil and South America have found similar situations, which confirm that the serology varies according to the degree of endemic of the geographic region, genetic predisposition of the population and level of proximity to the leprosy patient, in the case of household and social contacts ${ }^{(5,10)}$. The results of the research revealed that the health services performed late and inopportune diagnoses, due to the presence of changes in foot strength after treatment.

Other research carried out previously in the region where the studied municipality was located indicated late diagnoses and hidden prevalence of cases, although the municipality is not included in an area established as a priority for the leprosy program ${ }^{(13-14)}$.

These characteristics observed in areas considered non-priority for leprosy reinforce the discussions about the importance of intensifying the actions of the control program, regardless of the classification of endemic. The areas of low detection need to be investigated with the same concern of the hyper endemic areas, since they can become neglected spaces that contribute to the maintenance of the chain of 
transmission, especially if they are of high socioeconomic vulnerability ${ }^{(15)}$.

The fact that most of the positive cases are residents of the rural area of the municipality refers to the fact that the geographical distance hinders access to the health unit and is related to late diagnoses with greater bacillary burden and physical disabilities ${ }^{(13)}$.

The influence of living conditions and coexistence was very evident in this study. Positive cases and schoolchildren lived with more people in their homes, characteristics of urban clusters with greater social vulnerability. The descriptive analysis of the data revealed a population with low schooling and income around a minimum wage, which reinforces the affirmation that poverty, poor housing and lack of sanitation are closely related to leprosy ${ }^{(2)}$.

The profile of household contacts with positive serology - men over 60 years and spouses of the index case - also suggests that the length of time and exposure to the focus of the infection puts them at risk of acquiring the disease $\mathrm{e}^{(5,15)}$, corroborating the affirmation that a set of factors greatly influence the transmission of Mycobacterium leprae, in addition to the clinical features of the index case $\mathrm{e}^{(10)}$.

Among schoolchildren, average age was 11 years and IgM antibody levels were higher in girls. Similar results were found in a survey among healthy schoolchildren from a locality in the Amazon, Brazil ${ }^{(7)}$.

The positive serology among the students participating in this study (10.1\%) was proportionally lower than that found by other studies, $48.8 \%^{(7)}$ and $77.6 \%{ }^{(12)}$. However, the aforementioned surveys were carried out in sites with a much higher endemic level than the municipality of Diamantina. When considering the projections found in the literature ${ }^{(12)}$, a total of approximately 4,000 public school students from seven to 14 years of age in the municipality, 400 would be seropositive and around 40 could develop the disease, contrasting with the null detection rate in children under 15 years of age during the analysis period.

In the studied municipality, there was a heterogeneous distribution of leprosy cases among the cen- sus tracts and the emergence of a cluster of high risk of illness, a pattern demonstrated in other studies in Brazil and worldwide ${ }^{(2,8,15-16)}$. There was also a spatial-temporal relationship between the diagnosed cases, with a difference of up to three years and residents within a radius of 100 meters.

Spatial differences can occur due to socioeconomic vulnerability, population density, quality of life of the residents, migration patterns, environmental factors and health care ${ }^{(2,15,17)}$.

In this study, the clusters of illness and seropositive are similar in socioeconomic situation, but differ in relation to the coverage of the Family Health Strategy. The disease cluster is located in a region that has two health units, contrasting with the PGL-1 most seropositive sector, which has only one team and is lacking Community Health Agents to cover all micro-areas. The intensification of leprosy surveillance actions can increase the incidence of the disease in areas with greater access to health services ${ }^{(17)}$ and, subsequently, present a decreasing trend over the years ${ }^{(18)}$.

In this sense, spatial analysis reinforced the evidence of active and neglected chain of transmission. Faced with the concentration of seropositive, it is believed that there is an area of occult endemic disease in the municipality. Therefore, it is urgent to intensify the active search, in order to avoid underreporting, late diagnoses and physical disabilities ${ }^{(15)}$.

\section{Conclusion}

The serological analysis showed that the coexistence situation is related to the prevalence of $\mathrm{Myco}$ bacterium leprae infection, and the spatial analysis showed a hidden endemic leprosy scenario in the studied municipality, as well as the presence of the active transmission chain. This study may assist in directing leprosy control actions by municipal management and health professionals, as well as contribute to other municipalities that are not in cluster of priority actions, but present the same operational difficulties to increase the epidemiological surveillance of leprosy. 


\section{Acknowledgments}

To the Fundação de Amparo à Pesquisa de Minas Gerais, Brazil, for the approval of the project in Universal Announcement, 01/2016.

\section{Collaborations}

Ribeiro GC and Lana FCF contributed with project design, data analysis, writing and critical revision of intellectual content and final approval of the version to be published. Barreto JG assisted in data analysis, critical review of the intellectual content and approval of the final version. Bueno IC and Vasconcelos BF collaborated with article writing and critical review relevant intellectual content.

\section{References}

1. Ministério da Saúde (BR). Secretaria de Vigilância em Saúde. Departamento de Vigilância das Doenças Transmissíveis. Diretrizes para vigilância, atenção e eliminação da hanseníase com problema de saúde pública: manual técnicooperacional [Internet]. 2016 [citado 2018 out 13]. Disponível em: http://bit.ly/2upaIZ1

2. Freitas LRS, Duarte EC, Garcia LP. Analysis of the epidemiological situation of leprosy in an endemic area in Brazil: spatial distribution in the periods 2001 - 2003 and 2010 - 2012. Rev Bras Epidemiol. 2017; 20(4):702-13. doi: http:// dx.doi.org/10.1590/1980-5497201700040012

3. Ministério da Saúde (BR). Sala de Apoio à Gestão Estratégica. Situação de saúde. Morbidade - hanseníase [Internet]. 2018 [citado 2018 out 13]. Disponível em: http://sage.saude.gov.br/\#

4. Cardona-Castro NM, Restrepo-Jaramillo S, Gil OM, Brennan PJ. Infection by Mycobacterium leprae of household contacts of lepromatous leprosy patients from a post-elimination leprosy region of Colombia. Mem Inst Oswaldo Cruz. 2005; 100(7):703-7. doi: http://dx.doi.org/10.1590/ S0074-02762005000700003
5. Silva RC, Lyon, S, Araos, R, Lyon, AC, Grossi, MAF, Lyon, SH, et al. The result patterns of ML Flow and ELISA (PGL-I) serologic tests in leprosy-endemic and non-endemic areas. Rev Soc Bras Med Trop. 2008; 41(suppl 2):19-22. doi: http://dx.doi. org/10.1590/S0037-86822008000700005

6. Fabri ACOC, Carvalho AP, Araujo S, Goulart LR, Mattos AM, Teixeira HC, et al. Antigen-specific assessment of the immunological status of various groups in a leprosy endemic region. BMC Infect Dis. 2015; 15:218. doi: http://dx 10.1186/ s12879-015-0962-4

7. Barreto JG, Guimaraes LS, Frade MA, Rosa PS, Salgado CG. High rates of undiagnosed leprosy and subclinical infection amongst school children in the Amazon Region. Mem Inst Oswaldo Cruz. 2012; 107(Suppl 1):60-7. doi: http://dx.doi. org/10.1590/S0074-02762012000900011

8. Barreto JG, Bisanzio D, Guimaraes LS, Spencer JS, Vazquez-Prokopec GM, Kitron U, et al. Spatial analysis spotlighting early childhood leprosy transmission in a hyperendemic municipality of the Brazilian Amazon region. PLoS Negl Trop Dis. 2014; 8(2):e2665. doi: https://doi.org/10.1371/ journal.pntd.0002665

9. Moura ML, Dupnik KM, Sampaio GA, Nobrega $\mathrm{PF}$, Jeronimo AK, Nascimento-Filho JM, et al. Active surveillance of hansen's disease (leprosy): importance for case finding among extradomiciliary contacts. PLoS Negl Trop Dis. 2013; 7(3):e2093. doi: https://doi.org/10.1371/ journal.pntd.0002093

10. Carvalho APM, Coelho A, Correa-Oliveira R, Lana FCF. Specific antigen serologic tests in leprosy: implications for epidemiological surveillance of leprosy cases and household contacts. Mem Inst Oswaldo Cruz. 2017; 112(9):609-16. doi: http:// dx.doi.org/10.1590/0074-02760160505

11. Rada E, Duthie MS, Reed SG, Aranzazu N, Convit J. Serologic follow-up of IgG responses against recombinant mycobacterial proteins ML0405, ML2331 and LID-1 in a leprosy hyperendemic area in Venezuela. Mem Inst Oswaldo Cruz. 2012; 107(suppl 1):90-4. doi: http://dx.doi. org/10.1590/S0074-02762012000900015 
12. Barreto JG, Bisanzio D, Frade MAC, Moraes TMP, Gobbo AR, Souza Guimarães L, et al. Spatial epidemiology and serologic cohorts increase the early detection of leprosy. BMC Infect Dis. 2015; 15:527. doi: https://dx.doi.org/10.1186\%2 Fs12879-015-1254-8

13. Ribeiro GC, Lana FCF. Incapacidades físicas em casos de hanseníase: caracterização, fatores associados e evolução. Cogitare Enferm. 2015; 20(3):495-502. doi: http://dx.doi.org/10.5380/ ce.v20i3.41246

14. Ribeiro GC, Fabri ACOC, Amaral EP, Machado IE, Lana FCF. Estimativa de prevalência oculta de na microrregião de Diamantina-Minas Gerais. Rev Eletr Enf. 2014; 16(4):728-35. doi: http://dx.doi. org/10.5216/ree.v16i4.22371

15. Ramos AC, Yamamura M, Arroyo LH, Popolin MP, Chiaravalloti Neto F, Palha PF, et al. Spatial clustering and local risk of leprosy in Sao Paulo, Brazil. PLoS Negl Trop Dis. 2017; 11(2):e0005381. doi: https://doi.org/10.1371/journal.pntd.0005381
16. Brook CE, Beauclair R, Ngwenya O, Worden L, Ndeffo-Mbah M, Lietman TM, et al. Spatial heterogeneity in projected leprosy trends in India. Parasit Vectors. 2015; 8:542. doi: https://doi. org/10.1186/s13071-015-1124-7

17. Freitas LRS, Duarte EC, Garcia LP. Leprosy in Brazil and its association with characteristics of municipalities: ecological study, 2009-2011. Trop Med Int Health. 2014; 19(10):1216-25. doi: https://doi.org/10.1111/tmi.12362

18. Leano HAM, Araújo KMFA, Rodrigues RN, Bueno IC, Lana FCF. Indicators related to physical disability and diagnosis of leprosy. Rev Rene. 2017; 18(6):832-9. doi: http://dx.doi. org/10.15253/2175-6783.2017000600018 